\title{
elyRa
}

\section{mundo afazeres violetas}

algumas últimas palavras de Adília Lopes com algumas primeiras palavras de Adrienne Rich e uma frase da Björk

\section{Laura Erber}

sapo sempre avariado

circo prodigioso

morte carne beijos

mundo afazeres violetas

certamente viver adormecer

escrever dinheiro

figo

cró fíbula

Enid Blyton

anjo querida abelha

mulheres-a-dias ninguém significa

você fica tomado por essa intrusão e tem a impressão de que já não é mais você

que está falando

este coração nunca quente tortura

Marianna Édipo Espírito Santo

alquimistas mohicano 
Laura Erber

eu tu amor também

munidos dentro

escrevemos

Rio de Janeiro, 2016 